\title{
Oxidative Stress: Postharvest Fruits and Vegetables
}

\author{
sponsored by the \\ Postharvest Working Group
}

held at the

ASHS Centennial Conference

Providence, Rhode Island

6 October 2003 


\section{Presiding: Gene E. Lester}

Introduction to the Workshop

Gene E. Lester

Oxidative Stress: Importance for Postharvest Quality

D. Mark Hodges, Gene E. Lester, Kathleen D. Munro, and Peter T.A. Toivonen

Regulation of Oxidative Stress in Horticultural Crops

Albert C. Purvis

Oxidative Stress and Apple Scald

Bruce D. Whitaker

Postharvest Storage Procedures and Oxidative Stress

Peter T.A. Toivonen 